\title{
To marry a thief? Crime type as a deterrent to cohabitation
}

\author{
Joris Beijers ${ }^{1,2}$ • Jan Willem van Prooijen ${ }^{1,2}$ • \\ Catrien Bijleveld ${ }^{1,2}$
}

Published online: 24 February 2016

(C) The Author(s) 2016. This article is published with open access at Springerlink.com

\begin{abstract}
Objectives Using a vignette study, we investigated the relative attractiveness as cohabitation partners of five different types of offenders, male as well as female.

Methods Respondents advised a hypothetical person whether he or she should start cohabiting with his or her partner who had offended once. Gender and type of offence were systematically varied.

Results Our findings suggest that violent offenders are equally attractive as serious property offenders. Against expectation, perpetrators of relational violence are not rated as less attractive than other violent offenders, even if they are male, and also when females are the raters. Male violent offenders are rated as less attractive cohabitation partners than female violent offenders. Sex offenders are the least attractive cohabitation partners, particularly those who had offended against a child.

Conclusions Crime type matters: sex offending impacted consistently negatively on cohabitation advice. This effect may be partly due to the fact that many regard sex offenders as incurable and 'deviant.' Violent offending did not elicit markedly negative advice. Perhaps it was considered less of a risk because of the message in the vignette that the prospective cohabitants had a good relationship. It may also be that many young people have been in a fight or have slapped someone in their lives, and, therefore, downplay the seriousness of this offence.
\end{abstract}

Electronic supplementary material The online version of this article (doi:10.1007/s11292-016-9253-3) contains supplementary material, which is available to authorized users.

Joris Beijers

jbeijers@nscr.nl

1 VU University Amsterdam, Amsterdam, The Netherlands

2 NSCR - The Netherlands Institute for the Study of Crime and Law Enforcement, De Boelelaan 1077, 1081 HV Amsterdam, The Netherlands 
Keywords Cohabitation - Attractiveness · Offenders · Romantic partners · Vignette · Gender

\section{Experimental objectives}

We aimed to investigate whether offence type impacts on offenders' attractiveness as a romantic partner. In general, 'favourable' properties make people attractive marriage (and mating) partners. These are personal properties such as good looks and temperament, but also social properties such as having a job (Buss and Schmitt 1993), coming from a good family (Huschek and Bijleveld 2015), and socio-economic status (South 1991). The impact of incarceration on marriage chances has been studied fairly extensively, both at the micro (Apel et al. 2010) and the macro levels (Charles and Luoh 2010). Whether offending is by itself an unfavourable property that makes people less attractive romantic partners has been studied much less often (King et al. 2007). In the present study, we sought to expand on this research domain by examining if different crime types have different deterrent effects on cohabitation, which often is a prelude to marriage.

To assess whether offending affects people's chances on the relationship market is complicated, as the same underlying characteristics (such as temperament or intelligence) may influence both relationship formation and criminal behaviour. Some studies have attempted to overcome this by including static control variables or employing fixed effects models (e.g. Zoutewelle-Terovan et al. 2014). Many studies, however, have treated offending as one homogeneous 'signal.' As Zoutewelle et al. (2015) showed, different types of offending may affect relationship status differently.

This study investigated the causal effect of different types of offending on men and women's attractiveness as a cohabitation partner. The questions addressed are important, as crime is a so-called 'container' construct comprising behaviours that signal different types of deviance, and, for some crimes, may even signal masculinity or fierceness. Particularly for many young people, cohabitation is a preparatory step for family formation. We employ an experimental approach in which a number of vignettes are used to advise hypothetical persons whether they should cohabit with their romantic partner of one year who has once in his/her life committed one of five types of offences.

\section{Method}

We presented respondents with a hypothetical case in which a man or woman is considering cohabitation with their romantic partner of one year. The heterosexual couple was described as having an honest and satisfying relationship, so that there would be no reason to advise against cohabitation, although the attractiveness of the prospective partner may vary by the type of offence s/he has committed. The cases were manipulated to vary by gender and type of offence committed by the prospective partner. 
We varied offence type to represent relatively serious offences which we expected to elicit negative responses. They represented spread over type of offence (a property offence as well as violent offences), and different kinds of violent offences (offences committed in a public place as well as relationship violence, which might arguably be considered particularly negatively). Next, we included two kinds of sex offences, against a peer and against a child. Burglary was incorporated as a contrasting nonviolent but still relatively serious offence (it carries the heaviest sanction of all property offences in Dutch criminal law), against which we could gauge the answers for the various kinds of violent offences.

\section{Hypotheses}

We tested the following hypotheses:

H1: Male violent offenders are less attractive cohabitation partners than female violent offenders

H2: Offenders who have committed a violent or sexual offence are less attractive cohabitation partners than offenders who have committed burglary

H3: Offenders who have committed domestic violence are less attractive cohabitation partners than offenders who have committed a violent offence in a public setting

H4: Male offenders who have committed domestic violence are less attractive cohabitation partners than male offenders who have committed a violent offence in a public setting

H5: Female respondents rate offenders who have committed domestic violence as less attractive cohabitation partners than offenders who have committed public violence

H6: Offenders who have committed sexual violence are less attractive cohabitation partners than offenders who have committed non-sexual violence

H7: Offenders who have committed sexual violence against a child are less attractive cohabitation partners than offenders who have committed sexual violence against a peer

\section{Sample}

A total of 813 university students participated (283 men, 530 women; $\mathrm{M}_{\mathrm{age}}=21.31, \mathrm{SD}=2.93$ ). Students were asked to fill out a short questionnaire for one vignette during a class break. From one university in the Netherlands, classes were selected in Management Science, Communication Science, Anthropology/Political Science, Economics, Law, Biology, Psychology, Medicine and Informatics. While we aimed to achieve spread over different disciplines, the sample should be regarded as a convenience sample. Criminology and Criminal Justice classes were not sampled, as students might have been more aware of the manipulated variables. The data were gathered in May 2012. There was almost no item non-response $(<1 \%)$. A small number of students $(<5 \%)$ chose not to participate. 


\section{Vignettes}

Every student was presented with a standard vignette, in which two factors were manipulated in a balanced design: gender of the offender (two categories) and the type of offence the offender had committed (five categories); three other factors were varied as well, but due to limited space, and to keep this contribution focused, these will not be discussed here (information is available upon request). One example of the vignette ran as follows:

Ellen is 25 years old and a good friend of yours. She has been romantically involved with Bram for one year. Bram is 25 years old as well, and has had a job for two years, that will likely be turned into a permanent position. Ellen likes volleyball and swimming. Bram and Ellen want to make a next step in their relationship and start living together. Almost right from the start of their relationship, Bram confessed to Ellen that when he was 15 he committed a burglary in which he stole a sound system, cash, and a laptop from a house. Bram was convicted for this. Now that they are considering moving in together, Ellen realizes this once again. She does not know what to do.

She asks your advice.

The other categories for the offences were described as "punched someone, giving them a black eye during a fight" (violence in the public arena), "forced a child to have sexual contact" (child sexual abuse), "forced someone aged 14/24 (i.e. one year younger than the vignette-perpetrator's age when the offence was committed) to have sexual contact" (sexual abuse of a peer), "during a row with his/her then boyfriend/ girlfriend, punched him/her, giving him/her a black eye" (relational violence).

Each respondent was then asked what he or she would advise Ellen: "Would you advise Ellen to move in with Bram?", and to tick one of the categories 'certainly not', 'probably not', 'probably' and 'certainly'. As we offered only these options for an answer, we forced respondents to choose between positive or negative advice. Given that we asked for judgments on a four-point scale, an average score over 2.5 implies that, overall, the advice was positive, and a score under 2.5 that the advice was negative. Next, respondents filled in a number of demographic questions.

\section{Procedure}

Students were asked to fill out the one-page questionnaire in silence. Versions of the vignettes were randomly distributed (experimental design). We did ensure that successive vignettes varied by multiple experimental factors, so that respondents sitting next to each other could not easily single out a manipulation. Respondents in general filled out the questionnaires in around five minutes.

\section{Analytic methods}

The data were analysed by means of 5 (type of offence) $\times 2$ (offender's gender) between-subjects factorial ANOVAs. 


\section{Key research findings}

Figure 1 displays the mean scores for each of the five offence types. As the figure clearly shows, those who consider cohabiting with a burglar or violent offender received, on average, positive advice $(M>2.5)$. For sex offenders, this value was much lower. ${ }^{1}$

Consistent with Hypothesis 1, we found that male violent offenders were less attractive $(M=2.71, S D=0.06)$ than female violent offenders $(M=2.99, S D=0.06)$ $\left(\mathrm{F}_{1,319}=10.857, p=0.001\right)$. Our second hypothesis states that perpetrators of sexual and violent offences are less attractive prospective cohabitation partners than perpetrators of less serious (property) offences (i.e. burglary), but we found no support for this. Although the means were in the expected direction (violent offences $\mathrm{M}=2.57$, $\mathrm{SD}=0.03$; burglary $\mathrm{M}=2.70, \mathrm{SD}=0.07)$, the difference was not significant $\left(\mathrm{F}_{1,808}=3.453, p=0.064\right)$.

Next, we investigated differences between relational violence and public violence. First we investigated Hypothesis 3, which postulates that perpetrators of domestic violence are less attractive cohabitation partners than perpetrators of violence in a public setting. Although the means were in the expected direction (domestic violence $\mathrm{M}=2.80, \mathrm{SD}=0.06$; public violence $\mathrm{M}=2.92, \mathrm{SD}=0.06$ ), the difference was not significant $\left(\mathrm{F}_{1,319}=1.924, p=0.166\right)$. When we investigated this hypothesis (\#4) specifically for male offenders (domestic violence $\mathrm{M}=2.60, \mathrm{SD}=0.09$; public violence $\mathrm{M}=2.82, \mathrm{SD}=0.09)$, the differences were again not significant $\left(\mathrm{F}_{1,152}=3.270\right.$, $p=0.073$ ). When we looked at only female respondents (Hypothesis 5), still we found the same result: prospective male cohabiters were not considered significantly less attractive if they had committed domestic violence $(\mathrm{M}=2.58, \mathrm{SD}=0.11)$ than if they had committed public violence $(\mathrm{M}=2.82, \mathrm{SD}=0.10)\left(\mathrm{F}_{1,94}=2.926, p=0.090\right)$.

Next, we investigated differences between offenders of sexual and violent offences. First, we found support for Hypothesis 6: sex offenders $(\mathrm{M}=2.28, \mathrm{SD}=0.05)$ were significantly less attractive prospective cohabitation partners than violent offenders $(\mathrm{M}=2.86, \mathrm{SD}=0.05)\left(\mathrm{F}_{1,642}=80.252, p=0.000\right)$. Lastly, consistent with Hypothesis 7 , perpetrators of sexual violence against a child $(\mathrm{M}=2.16, \mathrm{SD}=0.07)$ were considered significantly less attractive than perpetrators of sexual violence against a peer $(\mathrm{M}=2.41, \mathrm{SD}=0.06)$ as prospective cohabitation partners $\left(\mathrm{F}_{1,321}=7.770, p=0.006\right)$.

\section{Conclusion}

Our study shows that crime type matters: sex offending impacted consistently negatively on cohabitation advice, with those who had offended against a child rated as the least attractive. This effect may be partly due to the fact that many regard sex offenders as incurable and specialist offenders and, thus, regard the risk of repetition as high, and partly due to the fact that sex offenders are regarded as 'deviant.' Violent offending, both in the public arena as well as committed against a former partner, did not elicit markedly negative advice, perhaps also considered less of a risk by the message in the vignette that the prospective cohabitants had a good relationship. Burglary, generally

\footnotetext{
${ }^{0}$ Descriptives are available as an online appendix.
} 


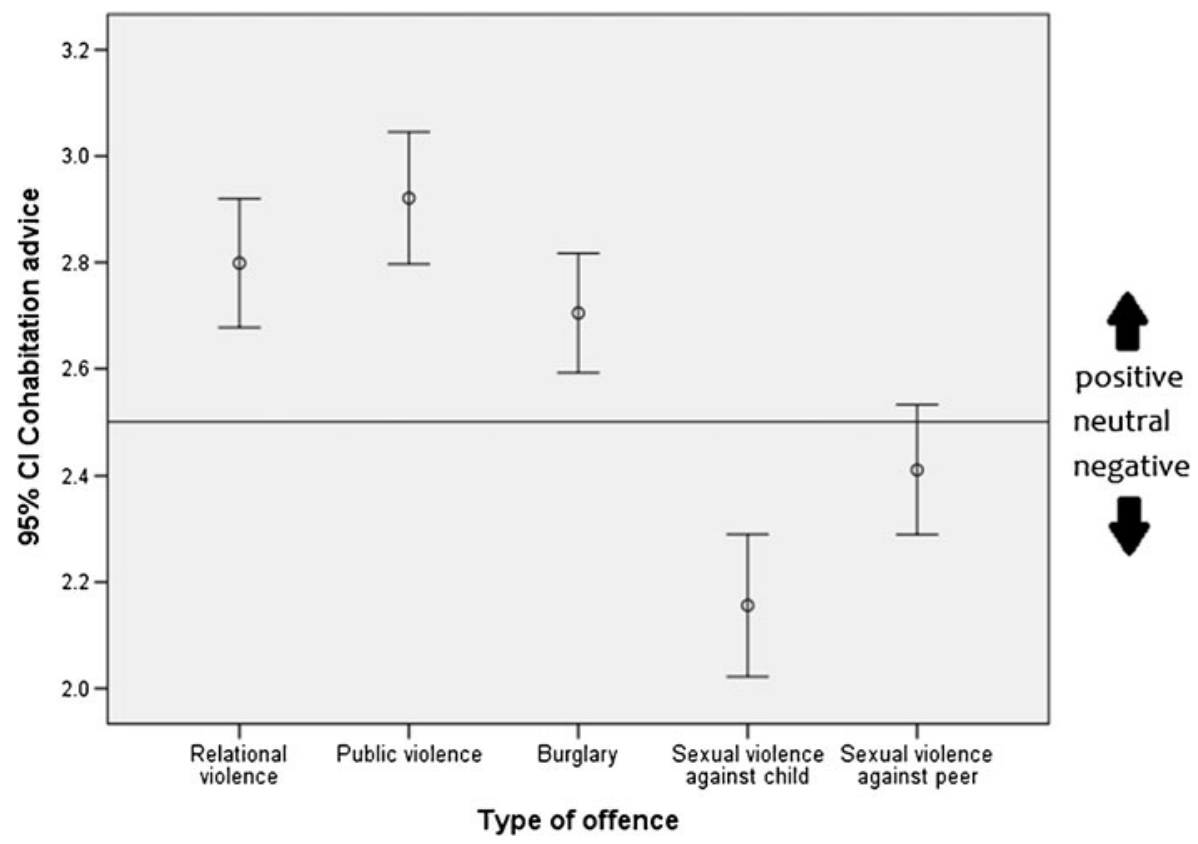

Fig. 1 Cohabitation advice as a function of type of offence

categorised by criminologists as a property offence and, therefore, as inherently less serious than a violent offence, ranks similarly to violence on the relationship market. It may be that many young people have been in a fight or have slapped someone in their lives, and, therefore, downplay the seriousness of this offence. All in all, our study shows that the objective seriousness of the offence does not relate ordinally with the attractiveness of prospective partners. Other aspects may be at play, such as the perceived 'creepiness' or 'otherness' that the offence signals.

The study has strong and weak points. While Henrich et al. (2010) argued against the use of 'WEIRD' (Western, Educated, Industrialised, Rich and Democratic) student samples, the students who served as respondents here are very well suited for the purposes of the study: they are emerging adults who are making, or will soon make, choices such as were pondered by the hypothetical persons in the vignettes, and are, in that sense, fairly close to the people they had to advise. On the other hand, our student sample may have been less than ideal, as the prevalence of offenders is likely lowest in the highly educated strata. Furthermore, we do not know to what extent the advice that students gave the hypothetical vignette person may be generalised to real-life decisions that people would make when it comes to their own demographic choices. While the study is strong on internal validity, its external validity may be low: the contrived nature of the vignette means that there is no tangible 'cost' to advising someone to cohabit, whereas they might perceive a very real cost to advising their own friends to do so. Another disadvantage is that our vignettes did not contain a 'null-person,' that is, someone who had not offended at all. It would have been hard to incorporate such a null-figure in the descriptions, as that would have made the cases unrealistic: without an issue such as the offending of the partner, it would have felt strange that 'Bram' or 'Ellen' hesitated at all. 
Possible extensions to our study lie in the comparison with a 'null-person' who has never offended, and the manipulation of factors such as whether the offender has been convicted and punished, and the time elapsed since the offence was committed.

Acknowledgements We wish to thank students Manuela van Barneveld, Annick van Duijl, Anne-Pauline Grotenhuis, Natascha Soekhoe and Christel van der Ven for assisting with the study design and collecting the data.

Open Access This article is distributed under the terms of the Creative Commons Attribution 4.0 International License (http://creativecommons.org/licenses/by/4.0/), which permits unrestricted use, distribution, and reproduction in any medium, provided you give appropriate credit to the original author(s) and the source, provide a link to the Creative Commons license, and indicate if changes were made.

\section{References}

Apel, R., Blokland, A. A. J., Nieuwbeerta, P., \& van Schellen, M. (2010). The impact of imprisonment on marriage and divorce: a risk set matching approach. Journal of Quantitative Criminology, 26(2), 269-300.

Buss, D. M., \& Schmitt, D. P. (1993). Sexual strategies theory: an evolutionary perspective on human mating. Psychological Review, 100(2), 204-232.

Charles, K. K., \& Luoh, M. C. (2010). Male incarceration, the marriage market, and female outcomes. The Review of Economics and Statistics, 92(3), 614-627.

Henrich, J., Heine, S. J., \& Norenzayan, A. (2010). Most people are not WEIRD. Nature, 466, 29.

Huschek, D., \& Bijleveld, C. C. J. H. (2015). Parental criminality and children's family-life trajectories: findings for a mid-20th century cohort. Longitudinal and Life Course Studies, 6(4), 379-396.

King, R. D., Massoglia, M., \& MacMillan, R. (2007). The context of marriage and crime: gender, the propensity to marry, and offending in early adulthood*. Criminology, 45(1), 33-65.

South, S. J. (1991). Sociodemographic differentials in mate selection preferences. Journal of Marriage and the Family, 53(4), 928-940.

Zoutewelle-Terovan, M., Van der Geest, V. R., Liefbroer, A. C., \& Bijleveld, C. C. J. H. (2014). Criminality and family formation: effects of marriage and parenthood on criminal behavior for men and women. Crime \& Delinquency, 60(8), 1209-1234. doi:10.1177/0011128712441745.

Zoutewelle, M., Van der Geest, V., Liefbroer, A. C., \& Bijleveld, C. C. J. H. (2015). The influence of criminal offending on union formation and union dissolution for disadvantaged individuals. Advances in Life Course Research. doi:10.1016/j.alcr.2015.08.001.

Joris Beijers studied criminology and is currently a PhD Candidate at the Department of Criminal Law and Criminology at VU Amsterdam. His research focuses on criminal careers and on the association between family factors and offending.

Jan-Willem van Prooijen is Associate Professor at the Department of Experimental and Applied Psychology at VU Amsterdam, and Senior Researcher at the Netherlands Institute for the Study of Crime and Law Enforcement (NSCR). His research focuses on the psychological processes underlying perceived injustice, conspiracy beliefs, and ideology.

Catrien Bijleveld studied psychology and criminal law. Her research interests are in the areas of criminal careers, female offenders, genocide, sex offending and the intergenerational transmission of offending. She is the author of several textbooks as well as of edited books, on crime and justice in the Netherlands, and on the association between employment and offending. 